\title{
The matter of the position of Jesus' burial cloths in a poetic text of the Orthodox Liturgy and in Iconography witnesses
}

\author{
Enrico Morini and Flavia Manservigi \\ Università di Bologna - Alma Mater Studiorum, Bologna, Italy
}

\begin{abstract}
The paper aims to analyze some interesting interpretations about the matter of the shape, the number and the position of Jesus' burial cloths as they were found by Peter and John in the empty tomb on Easter morning, in the light of some witnesses offered by Liturgy and Iconography.
\end{abstract}

\section{Introduction}

In the Gospels there is not a unanimous description of the burial cloths that were used to envelop Jesus' body on Friday evening.

In the Synoptic Gospels, it is affirmed that Joseph of Arimathea used, for this purpose, a sindòn [1]. In the Italian version of CEI (Conferenza Episcopale Italiana) this word is translated with "lenzuolo".

But Luke, in his Gospel, introduces a different word to describe the burial cloths that Peter saw into the empty tomb on Easter day: this word is othónia [2], and CEI translates it with "teli".

This term also appears in the Gospel of John (where the word sindòn is absent): the Evangelist uses it to describe the burial procedure of Jesus' body [3] and to refer to what Peter and John saw in the tomb on Sunday morning [4].

According to John, there was also another cloth in the tomb on Easter day, a soudárion (Italian translation: "sudario"), and he says that it was placed on the head of the defunct.

Another problem concerns the position that Jesus' burial cloths assumed in the sepulcher on Easter morning: in the Gospel of John we can read that Peter and John, after getting into the tomb, saw tà othónia in a particular position that is keimena (translated with "posati"), while the soudárion was allà khoris entetyligménon eis héna tópon. In the CEI translation this expression is given back as "non posato là con i teli, ma avvolto in un luogo a parte". But this translation is not satisfying, since it does not clarify the reason why John, after having seen the particular position of the burial cloths, believed in Christ's Resurrection (eîden kaì epísteusen) [5].

Those different descriptions lead to the problem of the compatibility among the various Gospels, and also to the one of the effective number and shape of the burial cloths that enveloped Christ's body after the Crucifixion. The problem emerging from the apparently conflicting witnesses of the Gospels about this matter becomes even more meaningful if related to the cloth that, according to tradition, enveloped Jesus' body before the Resurrection: the Turin Shroud.

This is an Open Access article distributed under the terms of the Creative Commons Attribution License 4.0, which permits unrestricted use, distribution, and reproduction in any medium, provided the original work is properly cited. 
Is it possible to reconcile the four Evangelists' narration with this wonderful object? And another question emerges because of those statements: was the Shroud the first sign of Christ's Resurrection, and the fundamental proof that led the Apostles to the first act of faith in the victory of Life on Death?

Those questions gave life to a wide historiographical debate, which can be extended to many research fields, such as Liturgy and Iconography.

\section{Analysis of the text concerning Jesus' burial cloths in the modern studies}

Many 20th century scholars analyzed with particular attention the verse of John's Gospel, trying to understand the real meaning of the words othónia and soudárion, and also their eventual relationship with the sindòn of the Synoptic Gospels.

Some scholars believe that othónia is a generic term indicating a textile product; it would include both the sindòn and some bandages or strips that were used to fasten the big sheet (that is the sindòn) upon Jesus' body [6].

According to others, othónia is an extended plural, used to talk about a unique, big sheet (so the term would be a synonymous of sindòn) [7].

Other ones believe that sindòn indicates the textile material of whom were made the othónia, and these would be the fastening strips that were used alone (and not together with a sheet) to roll up Jesus's body, maybe during the transportation from the Golgotha to the tomb [8].

For what concerns the soudárion, some scholars identify it with a chin rest that was used to keep closed the mouth of the defunct [9].

Others believe that this word derives from the Aramaic (soudarâ), and it can be identified with a large cloth, that is the sindòn [10].

Other ones state that it was a small cloth, put on the face of the defunct with various functions [11].

Scholars also wondered about John's description of the position of the burial cloths inside the sepulcher on Easter morning, trying to understand the reason why the young disciple, after having seen them, believed in Christ's Resurrection. The wide bibliography concerning this issue does not allow relating all the different theories. What is important to highlight is the fact that, even if modern scholars have not reached a unanimous opinion about the complex matter of Jesus' burial cloths, the majority of them does not consider the witness of John's Gospel in disagreement with the other Evangelists' one. The great part of the modern critic agrees upon the hypothesis that John believed because he saw the burial cloths lying on the funerary stone: after the Resurrection, the cloths were deprived of the body, but they did not change their position, since the body itself came through them as if it was transparent [12].

\section{The position of the burial cloths in the orthodox liturgy}

A liturgical text currently used in the Greek Orthodox Church faithfully reproduces the interpretation of the disposition of Christ's burial cloths in the empty tomb as it had circulated in the Eastern Christian world (the anonymous poet clearly took it from his preferential exegesis of John's verse made by the Church Fathers, as we will see). From this text it is possible to infer that it was exactly the position of the cloths which convinced both the Apostles of the truth of the Resurrection.

This is the second of the Kathismata Anastasima after the first stichology (the psalms' recite) in the Matins (orthros) of the Sunday of the Fourth Plagal Tone, regulated in the Paraklitiki of the Oktoikos (Book of Eight Tones, or Modes).

This is the text: "Truly resurrected from the tomb, you ordered to the Holy Women to announce the Resurrection to the Apostles, as it is written. Peter came running at the tomb and, when he saw 
the light in it, he was astonished. Thanks to the light he also saw the isolated cloths, lacking of the divine body, lying inside it (tà othónia móna chōrìs tou theíou sōmatos en autō katakeímena), and so he believed and then shouted: honor to you, God Christ, because you save everyone, our Savior. You are the Father's irradiation indeed" [13]. It is not easy to date this troparion, which has not been written for the Paraklitiki (which is a collection of various texts). Almost surely the kathismata anastasima belong to the liturgical tradition of Jerusalem, although we do not know their original destination: we only know that, in the liturgical summary made in Constantinople in the Stoudios monastery (where the Paraklitiki was composed), they have been added after the kathismata of the psalter (hence their name). The oldest text reproducing them is the stichero-kathismatarion of Jerusalem, located in two Sinai codes (the Greek 1593 and the 776) and dated to the 11 th century.

The fact that those texts were written in Jerusalem is meaningfully confirmed by the fact that the Orthodox tradition bestows the composition of the whole Paraklitiki on St. John of Damascus.

The poet merges the account of Luke's Gospel [14], which presents the character of Peter and his first reaction of wonder, and that of John's Gospel [15], from which he takes the second reaction, the act of faith in the Resurrection (epísteusas), which in that case does not come from Peter but from John himself. The expression othónia keímena can be found in both the texts, but Luke adds - unlike John - that they are isolated (móna), giving thus a first interpretation of John's verse: the apostle's wonder comes from the fact that the funerary cloths are empty. The Troparion further emphasizes the meaning of Luke's móna in the sense of "deprived of the divine body (chōrìs tou theíou sōmatos)" and it bestows on Peter the act of faith originally recorded for John, adding also a meaningful interpretation of the whole episode: what leads the apostle to faith is the burial cloth which maintained its original horizontal position, without any change due to the exit of the body enveloped into it.

This text is interesting also for another reason: the hint at the light shining in the tomb which allows the Apostle to see, even if it was still dark (this is also an allusion to the fact that Christ is the Father's irradiation, as indicated at the end of the tropary). It is a totally extra biblical information, but it is possible to find it in the Greek Patristic: one of the first mentions can be found in the second cathedral homily on the Resurrection of Severus of Antioch (it was wrongly bestowed to Gregory of Nissa in Migne's Patrologia Graeca [16] but it has been re-attributed to the anti-Chalcedonian patriarch by the recent editors, Kugener and Triffeaux, in the Patrologia orientalis). Here it is stated that "the tomb was full of light" and for this reason "those who were with Peter [...] even if it was night, could see the whole tomb" [17]. Similarly St. John of Damascus, in his homily on the Holy Saturday, hints at the "Sunday (of Easter) light bearer, when the uncreated light physically proceeds from the tomb" [18].

So John establishes a continuity between this uncreated light (which would have lightened the whole tomb on Easter morning) and the phenomenon of the Holy Fire - which is widely documented in literary texts having different religious and cultural origins, with a wide diachrony - that still today is part of the ritual celebrated every year by the Orthodox patriarch, together with the Armenian one, in the Holy Sepulcher church during the Holy Saturday morning.

Contemporary Orthodox theologians relate it - according to the criterions of the Palamita theology - to the light of the Transfiguration, to the fire of Pentecost and to the radiance which surrounded Paul on the road to Damascus, and they state that at the beginning it is a uncreated light, which suddenly, moving from devoted to devoted, becomes created fire.

This tradition could be very interesting for the studies on the Turin Shroud, specifically for the problem of the origin of the human imprint on the cloth. Giulio Fanti, from the University of Padua, suggested that the creation of the image on the cloth was the result of partial electric discharges, defined "crown effect" [19]. We can highlight that in 2008 the Russian physicist Andrej Volkov (from the Russian Kurčatov Institute) observed the presence in the air, at the moment of this ritual, of a strong electrostatic field, which leads to a remarkable potential difference and also to an electric discharge at the moment of the appearance of the Holy Light in the tomb [20]. 


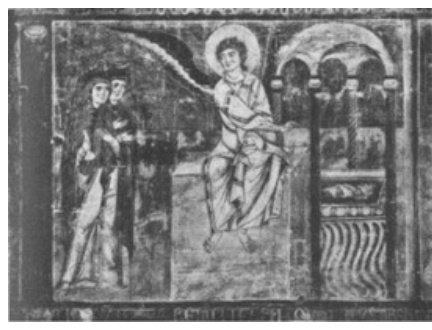

Figure 1. $11^{\text {th }}$ century fresco from Sant'Angelo in Formis.

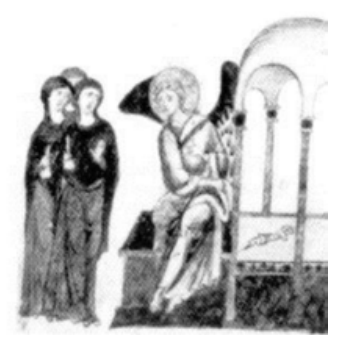

Figure 2. The Mazarina Breviary, $11^{\text {th }}$ century.

So the kathisma provides a double statement: it witnesses how, in the Mother Church of Jerusalem - preferential custodian of the holy memories of Christ's Passion and Resurrection - it was possible to read, between the 7th and the 9th century, the tà othónia keimena of the Gospels' verses and, at the same time, it witnesses that the Holy Fire was interpreted like the annual repetition of the effusion of the uncreated light which would have accompanied the event of the Resurrection. So it seems possible to outline a hypothetical answer to the open question of the formation of the image on the Turin Shroud, even if in a perspective that is not susceptible of scientific validity, but only of a philosophical and religious one.

\section{Christ's burial cloths in art}

Another important research field for the analysis of the problem of the number and position of Christ's burial cloths is Iconography.

The theme of Christ's Resurrection is one of the most illustrated in all the times. Jesus' burial cloths are often represented within the episode of the Myrrhbearers who went on Jesus' tomb on Sunday morning. This scene is centered on the meeting among the women and one or more angels who indicate the tomb lacking of the corpse, but still containing the burial cloths. The arrival of John and Peter at the sepulcher is hardly ever represented.

From the analysis of the iconographical statements emerged two different ways of representing the burial cloths, one typical of Western art, and one more linked to the Byzantine one (developed in the Greek, Russian and Slavic contexts).

In Western art, it is often represented only a cloth, of small size and lacking of a defined shape. It is usually depicted as tied on itself.

We can see it, for example, on a fresco of Sant'Angelo in Formis (Fig. 1, 11th century) [21], on the Mazarina Breviary (Fig. 2, 11th century) [22], on a Dome Gospel Book from Padua (Fig. 3, 


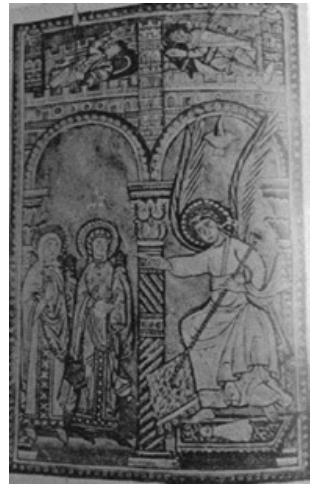

Figure 3. $12^{\text {th }}$ century Dome Gospel Book from Padua.

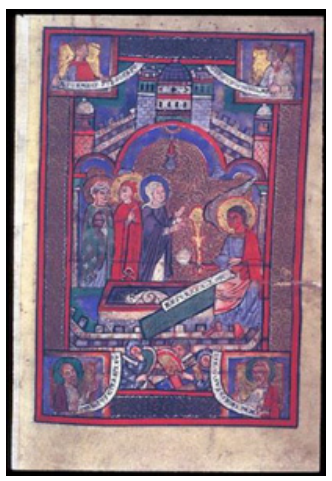

Figure 4. Psalter of Henry the Lion, $12^{\text {th }}$ century.

12th century) [23], on the Psalter of Henry the Lion (Fig. 4, 12th century) [24], and on some depicted crosses of the Italian tradition, dated between the 12th and the 13th century [25].

On the other hand, in the Byzantine world burial cloths are represented in two different ways, both very particular: in the first case, we have two cloths, one bigger and made of strips (similar to a mummy bandage; it is possible to identify it with the othónia), and the other one separated from this and similar to a hat (identifiable with the soudárion). They both have a shape similar to a cocoon, as if they were still enveloping a body. Furthermore, they are often in a vertical position. Some examples of this iconography can be found on a cover plate of the Reliquary of the Holy Sepulcher Stone (Fig. 5, 10th century) [26], on a fresco from the Transfiguration Cathedral of the Mirozhsky monastery (Pskov) (Fig. 6, 12th century) [27], on the frame of a mosaic icon from the Vatopedi monastery on the Mount Athos (Fig. 7, 13th 14th century) [28], on a fresco from the church of St. Nicholas of Prilep (Fig. 8, 13th - 14th century) [29] and on a miniature of the Armenian Gospel Paris. Arm. 18, leaf 25 (Fig. 9, 15th century) [30].

In the second iconographical group we can see the two cloths (a biggest one, of the size of a human body, corresponding to the othónia, and a smaller one set in the place of the head, and so identifiable with the soudárion), both lying on the burial stone, emptied after the coming out of the body. Some examples are a fresco from the Russian monastery of Kirillo-Beloserskij (Fig. 10, 14th century) [31], a fresco from the Church of the Pantokrator of the Serbian monastery Visoki Dečani (Fig. 11, 14th century) [32], 


\section{SHS Web of Conferences}

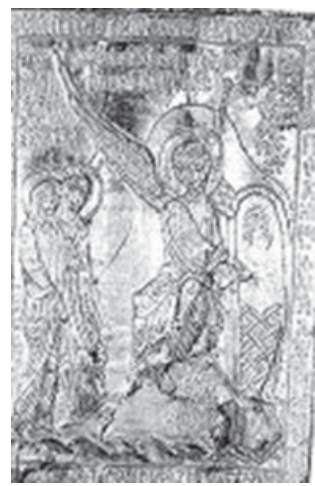

Figure 5. $10^{\text {th }}$ century cover plate of the Reliquary of the Holy Sepulcher Stone.

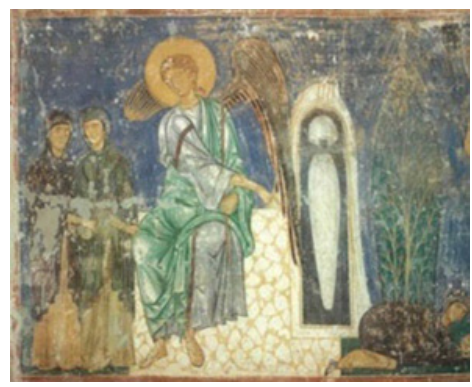

Figure 6. $12^{\text {th }}$ century fresco from the Transfiguration Cathedral of the Mirozhsky monastery (Pskov).

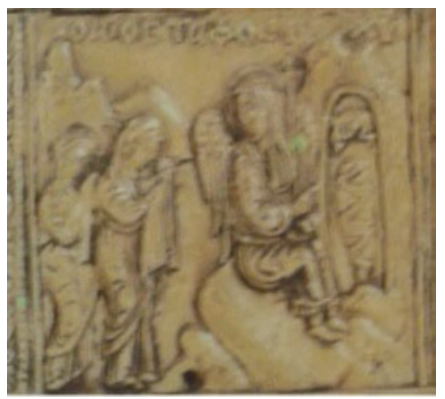

Figure 7. Frame of a mosaic icon from the Vatopedi monastery, $13^{\text {th }}-14^{\text {th }}$ century.

a 15th century icon from Novgorod (Fig. 12) [33], a 15th century icon from Rublëv's laboratory (Fig. 13) [34] and an icon from the Russian city of Vologda (Fig. 14, 15th-16th century) [35].

So it seems possible to state that in the Byzantine tradition the shape and position of the burial cloths are considered the principal elements that led to John's act of faith. The peculiarity of what the two apostles saw is highlighted not only by the shape of the cloths, which maintain the position they had at the moment of the burial, but, in most cases, also from their position, which is completely vertical. This deeper comprehension may have come from the interpretation of John's verse in the Greek Patristic: the Greek Church Fathers connected John's act of faith to the position of the cloths, unlike the Latin ones, 


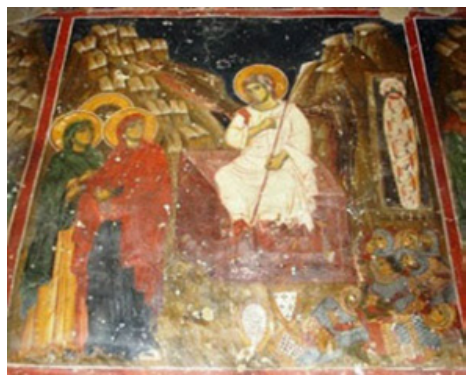

Figure 8. Fresco from the church of St. Nicholas of Prilep, $13^{\text {th }}-14^{\text {th }}$ century.

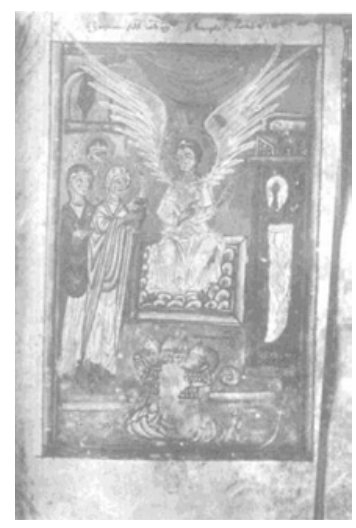

Figure 9. $15^{\text {th }}$ century miniature of the Armenian Gospel Paris. Arm.18, leaf 25.

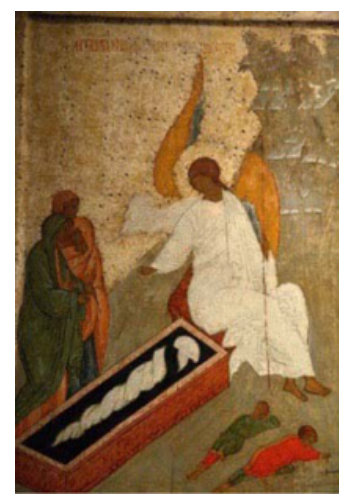

Figure 10. $14^{\text {th }}$ century fresco from the Russian monastery of Kirillo-Beloserskij.

who stated that the Apostles believed in the Resurrection simply because they saw that the body was no more in the sepulcher [36]. It is very interesting to notice the resemblance between the word used by Cyril of Jerusalem, who defines what Peter and John saw into the tomb as extraordinary, paràdoxos, and the position of the vertical cloths in Byzantin representations, which is extraordinary indeed. It is very interesting also the interpretation of Nonnus of Panopolis, who supposed that John, after the sight of the 


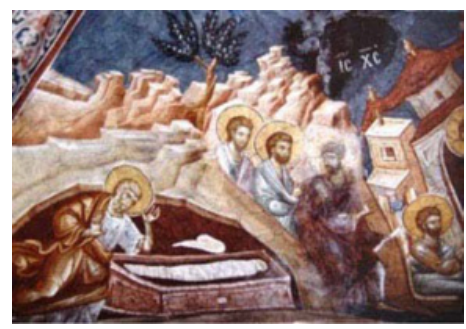

Figure 11. $14^{\text {th }}$ century fresco from the Church of the Pantokrator of the Serbian monastery Visoki Dečani.

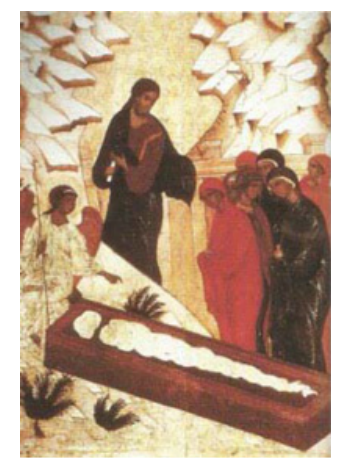

Figure 12. $15^{\text {th }}$ century icon from Novgorod.

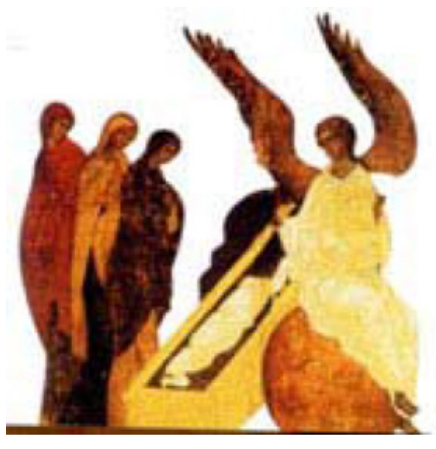

Figure 13. $15^{\text {th }}$ century icon from Rublëv's laboratory.

position of the burial cloths, believed that Jesus' body had become transparent and had flown beyond the Earth's limits [37].

The analysis of the Eastern iconographical witnesses seems to offer also some information about the interpretation of John's verse in ancient times: iconographical sources convey the idea that the term othónia was interpreted as a sort of bandage (in a shape similar to the ones of mummies), while the soudárion was interpreted like a sort of hat; it is interesting to observe that it was never represented as put in a place aside in respect to the othónia, but it was always pictured as wrapped around itself and placed above the bandage, at a certain distance from them. In the first iconographical type, both cloths are represented in a very particular way, since they do not only maintain an unaltered shape, but they are also both in a vertical position. For this reason it could be possible to suppose that in the ancient Greek 


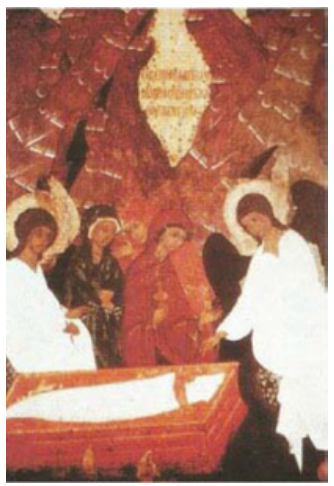

Figure 14. icon from Vologda, $15^{\text {th }}-16^{\text {th }}$ century.

world the expression eis héna tópon, which was usually interpreted as referred only to the soudárion, was actually related to both the cloths, which had assumed an exceptional, unique and extraordinary position after the Resurrection.

From iconography it seems possible to deduce that John 20, 5-7 was interpreted as follows in the ancient Eastern context:

tà othónia $=$ the bandages;

keimena $=$ lying, according to the part of the tradition where they are represented on the stone emptied of the body (a tradition that was followed also by the author of the troparion); in the cases where they are represented as still enveloping the body, the word could be interpreted as "in the same position they had before";

kaì tò soudárion $=$ and the cloth;

hò ên epì tês kephalês autô̂ = that had been on Jesus' head: not on his face (as some scholars supposed), but right upon his head, like a sort of hat;

ou metà tôn othoníon keímenon = not lying together with the bandages;

allà khoris entetyligménon $=$ but wrapped (as if it was still wrapping the head of the defunct) aside (not in another place, but discontinuously).

eis héna tópon $=$ both in a particular/exceptional/unique position.

But how does this interpretation fit with the Turin Shroud? In the iconographical witnesses Jesus' burial cloths are never represented in the shape of a unique, wide sheet. Nevertheless, this is not an element contrasting with the possibility that Jesus' body was enveloped in a shroud: first of all, all the Synoptic Gospels talk about the sindòn. Secondly, one of the most meaningful theories about the real meaning of the terms othónia and soudárion is based on the possibility that a bandage and a sort of headgear were actually outside of the shroud, in order to better fasten it to the body or maybe to preserve the aromas and scents that had been used during the burial rituals. It is not possible, thus, to exclude the possibility that othónia and soudárion coexisted with the sindòn; on Easter morning, Peter and John would have seen first the bandages and the head cloth, because they were the most external part of the burial cloths.

According to this perspective, it is possible that the artists chose to represent the burial cloths in a way that made immediately understandable to those who observed the extraordinariness of what John and Peter had seen in the tomb. Only representing two different clothes (the "bandages" and the "hat") it was possible to convey the idea of the Resurrection: the representation of a unique sheet maintaining the shape of a human body would not have allowed communicating the idea that the corpse had actually disappeared. Only through the representation of two different and separate cloths, and of the space that 
had been originated between them because of the disappearing of the corpse, it was possible to point out that Christ's body was no more in the tomb, but it had gone away in an extraordinary way. For this representation, artists relied alternatively on the account of the Synoptic Gospels (like for the theme of the Myrrhbearers' arrival at the tomb, which is not mentioned by John) and that of John's Gospel, in order to have, from time to time, the most suitable elements to make clear what happened on Easter morning.

\section{Conclusion}

The witnesses taken into account (both the poetical one of the Orthodox troparion, and the iconographical ones typical of Eastern art) show two interesting examples of the same interpretation of Luke's and John's verses: the disciples' act of faith derived from the particular position of Christ's burial cloths. In the poetical text it is expressed through the category of wonder, derived from the sight of the cloths in the shape of an empty shell. In iconography, on the other hand, next to this interpretation (reproducing the cloths "empty of the Divine body"), another one can be observed, where the burial cloths are depicted in a singular vertical position. This position, according to us, is an attempt to reproduce with more emphasis Peter and John's wonder.

However, it does not seem to us that the different words used by Luke and John to designate Christ's burial cloths can be interpreted - because of their general nature - in a univocal and certain way, also because the different Gospels are the written expression of different traditions, as it can be seen in other more meaningful contexts.

For a correct principle of New Testament exegesis, the different - and sometimes conflicting details of the single narrations always converge in a common statement, which represents the historical data and that, in this case, is represented by the position of the burial cloths - whatever they were - as incontrovertible evidence of the Resurrection.

\section{References}

[1] Mt 27, 59; Mk 15, 46; Lk 23, 53

[2] Lk 24, 12

[3] Jn 19, 40

[4] Jn 20, 5-7

[5] Jn 20, 8

[6] A. Vaccari, "Archeologia e scienze di fronte al testo sacro dei Vangeli", in La Sacra Sindone nelle ricerche moderne, Torino (1950) (Atti del Convegno Nazionale 1939), 181-194; P. Barbet, La passione di N.S. Gesù Cristo secondo il chirurgo, italian translation by G. Bellardo, Torino (1951), 32; A. Feuillet, "L'identification et la disposition des linges funéraires de la sépulture de Jésus d'après les données du quatrième Evangile", in La Sindone e la scienza. Atti del II Congresso Internazionale di Sindonologia, Torino 7-8 ottobre 1978, by P. Coero Borga, Torino (1979), 239-251; F. Spadafora, La Risurrezione di Gesù, (2010), 85

[7] See in particular C. Lavergne, "La preuve de la Résurrection de Jésus d'après Jean 20, 7", Sindon, III, 5, 7 (1961), 21

[8] J. Blinzer, Il processo a Gesù, (1966), 361

[9] C. Lavergne, "La preuve de la Résurrection de Jésus d'après Jean 20, 7", op. cit., 14; A. Feuillet, "L'identification et la disposition des linges funéraires de la sépulture de Jésus d'après les données du quatrième Evangile”, op. cit., 240; J.A.T. Robinson, "The Shroud and the New Testament", in La Sindone e la scienza, op. cit., 269. This hypothesis is suggested also by C. De Cidrac, Professor at the Institute Catholique of Paris. He also suggested that the negation ou was not referred to the otonion, but to the participle keimenon: this expression would indicate that the soudárion was not 
stretched with the bandages, but it had remained under the other cloths, clearly rolled up in its own place (eis ena tópon). Cidrac's exegesis has not been published in any scientific publication, but only on the periodical 30 giorni (July/August 2000), 68-69

[10] See in particular E. Levesque, "Le Saint Suaire de Turi net l'Evangile", Nouvelle Revue apologétique, (1939), 225-237; P. Barbet, La passione di N.S. Gesù Cristo secondo il chirurgo, op. cit., 32 et seq.; B. Bonnet-Eymard, "Il "Soudarion" Giovanneo negativo della gloria divina", in La Sindone: scienza e fede, Atti del II convegno nazionale di sindonologia, Bologna, 27-29 novembre 1981, ed. by L. Coppini, F. Cavazzuti, Bologna (1983), 91-105, 98

[11] J. Blinzer, Il processo a Gesù, op. cit., 362; G. Ricci, L'Uomo della Sindone è Gesù, Milano (1985), 232; F. Spadafora, La Risurrezione di Gesù, op. cit., 87

[12] See in particular F.M. Willam, Vita di Gesù, Freiburg im Breisgau, (1933), italian translation by B. Pastore, (1937), 479; M.J. Lagrange, Évangile selon Saint Jean, Paris (1948), 508; L. Salleron, "Les lignes du tombeau vide à la Résurrection", La Pensée Catholique, n 163, (1976), 16-18; A. Feuillet, "L'identification et la disposition des linges funéraires de la sépulture de Jésus d'après les données du quatrième Evangile", op. cit., 252-263; G. Ricci, L'Uomo della Sindone è Gesù, op. cit., 232; A. Persili, Sulle tracce del Cristo Risorto: con Pietro e Giovanni testimoni oculari, (1988); F. Spadafora, La Risurrezione di Gesù, op. cit., 141

[13] Anthológion tou hólou eniautou, Teukos A. Romi, (1967), 515; Paraklitikì tou Oktoíchou, Apostoliki Diakonía tis Ekklisìas tis Helládos, Athinai (1992), 628

[14] Lk 24, 12. In the edition of E. Nestle and K. Aland (1963) this verse is placed in the critical apparatus - it was evidently considered a later interpolation on the bases of John's verse -, nevertheless it is acknowledged not only in the edition of A. Merk (1933), but, for what concerns the official use of the two Churches, both in the Latin New Vulgate of 1979 (in the form it had in the Clementine Vulgate of 1592), both in the edition of Constantinople and Athens of 1928-29

[15] Jn 20, 6-8

[16] Gregorius of Nyssa, In Christi resurrectionem oratio II, PG 46, cc. 627-652: 636 D

[17] Les Homiliae Cathedrales de Sévère d'Antioche, ed. by M.A. Kugener \& E. Triffaux in PO 16, Hom. LXXVII, 814-820

[18] John of Damascus, Homilia in sabbatum sanctum, PG 96, cc. 601-644: 628

[19] G. Fanti, “Can a Corona Discharge Explain the Body Image of the Turin Shroud?", Journal of Imaging Science and Technology, LIV, 2, (2010), 1-10; Id., "Hypotheses Regarding the Formation of the Body Image on the Turin Shroud", Journal of Imaging Science and Technology, LV, 6, (2011), 5-7; Id., La Sindone. Una sfida alla scienza moderna, Roma (2008), 259-281; G. Fanti, S. Gaeta, Il mistero della Sindone. Le sorprendenti scoperte scientifiche sull'enigma del telo di Gesù, Milano (2013), 131-157; G. Fanti, P. Malfi, Sindone: primo secolo dopo Cristo!, with deepenings by M. Conca, Fano (PU) (2014), 34-42

[20] Ch.K. Skarlakidis, La Santa Luce. Il miracolo della vigilia della Santa Pasqua nel sepolcro di Cristo, Atene (2012), 165-170

[21] E. Sandberg-Vavala, La croce dipinta italiana e l'iconografia della passione, Verona (1929), Fig. 295

[22] V. Vannucci, Maria Maddalena. Storia e iconografia nel Medioevo dal III al XIV secolo, Roma (2012), 70, Fig. 13a

[23] A. Venturi, Storia dell'arte italiana, Milano, III, Fig. 425

[24] It is preserved at the British Library; http://www.bl.uk/catalogues/ illuminatedmanuscripts/record. asp?MSID=7892\&CollID15\&NStart=381

[25] See E. Sandberg-Vavala, La croce dipinta italiana e l'iconografia della passione, op. cit., 289 et seq

[26] V. Vannucci, Maria Maddalena, op. cit., Fig. 3 


\section{SHS Web of Conferences}

[27] Pskov: art, treasures and architectural monuments: XII-XVII centuries: architectural monuments, ancient fortresses, Izborsk and Pechory, frescoes, icons of the Pskovian school, minor arts, illuminated MSS, ed. by S. Yamshchikov, Leningrad (1978), pl. 21

[28] Treasures of Mount Athos. Thessaloniki: Holy Community of Mount Athos, Organization for the cultural capital of Europe, Thessaloniki (1997), 70, 2.12

[29] G. Millet, La peinture du Moyen Age en Yougoslave (Serbie, Macédonie et Monténégro), Paris (1954), III, pl. 26.3

[30] F. Macler, Miniatures armeniennes: vies du Christ, peintures ornementales (X au XVII siecle), Parigi (1913), pl. XVIII, 42

[31] A.I. Komec, La Russia dei monasteri, Milano (2011), 94 et seq

[32] See S. Cicrcovic, I Serbi nel Medioevo, Milano (1992), 224 et seq.; see also P. Mijovic, Decani, Beograd (1974)

[33] L. Mirri, "L'icona alfabeto della fede. Che cosa vide e perché credette l'evangelista Giovanni", in Le icone di Cristo e la Sindone: un modello per l'arte cristiana, ed. by L. Coppini, F. Cavazzuti, Bologna - Cinisello Balsamo (2000), 204-215, Fig. 2

[34] Id., Fig. 3

[35] Id., Fig. 1

[36] See P. Savio, Ricerche storiche sulla santa Sindone, Torino (1957), 131 et seq

[37] PG 43, 907 